\title{
Bireysel Banka Müşterilerinin Demografik Özellikleri ile Kredi Kartına Yönelik Tutumları Arasındaki İlişkinin İncelenmesi \\ (Investigation of The Relationship Between Demografic Features of Individual Bank Customers and Attitude Towards The Credit Card)
}

\author{
Zekeriya GÜL (iD a Orhan İSCAN iD b Hande AYHAN GÖKCEK iD c \\ a Cumhurbaşkanlığı, Sağlık ve Gıda Politikalar Kurul Sekreteri, Ankara, Türkiye. zgul4606@gmail.com \\ b İstanbul Gelişim Üniversitesi., Yönetim Bilişim Sistemleri, İstanbul, Türkiye. oiscan@gelisim.edu.tr \\ c İstanbul Gelişim Üniversitesi, Yönetim Bilişim Sistemleri, İstanbul, Türkiye. hayhan@gelisim.edu.tr
}

\begin{tabular}{|c|c|}
\hline MAKALE BİLGİSİ & ÖZET \\
\hline $\begin{array}{l}\text { Anahtar Kelimeler: } \\
\text { Kredi Kartına Yönelik Tutum } \\
\text { Tüketici Davranışları } \\
\text { Bireysel Banka Müşterisi } \\
\text { Katılım Bankası }\end{array}$ & $\begin{array}{l}\text { Amaç - Bankacılık sektörü, müşterilerin demografik özelliklerine göre kredi kartı tutumları açısından } \\
\text { oldukça önemli bir yere sahiptir. Rekabetin yoğun olduğu bir dönemde bankaların, müşterilerinin } \\
\text { tercihlerinde doğru tespitlerinin yapılması için gerekli araştırma yapması açısından kredi kartı } \\
\text { tutumlarının incelenmesi önemlidir. Bu araştırmanın amacı, katılım şubelerindeki bireysel banka } \\
\text { müşterilerinin demografik özellikleri ile kredi kartına yönelik tutumları arasındaki ilişkiyi ortaya } \\
\text { çıarmaktır. Ankara ilindeki katılım banka şubesinde gerekli çalışmalar yapılmıştır. }\end{array}$ \\
\hline $\begin{array}{l}\text { Gönderilme Tarihi } 24 \text { Şubat } \\
2021 \\
\text { Revizyon Tarihi } 31 \text { Mayıs } \\
2021 \\
\text { Kabul Tarihi } 20 \text { Haziran } 2021\end{array}$ & $\begin{array}{l}\text { Yöntem - Araştırmanın amacına uygun olarak belirlenmiş̧ olan } 2020 \text { yılı birinci ve ikinci dönem ilk altı } \\
\text { aydaki kredi kartı kullanan } 193 \text { bireysel banka müşterisinin vermiş olduğu cevaplar doğrultusunda } \\
\text { inceleme yapılmıştır. G*Power Version 3.1.9.6 programı kullanılarak Ankara ilinde yer alan katılım } \\
\text { banka şubelerindeki bireysel banka müşterilerinden kredi kartı kullanan kişiler arasından evreni } \\
\text { oluşturan } 111782 \text { bireysel banka müşterisi içerisinden örneklemin gücüne göre sayısı belirlenmiştir. } \\
\text { Kolayda örnekleme yöntemi ile anket uygulaması yapılmıştır. Analizler SPSS istatistik programı ile } \\
\text { yapılmıştır. Frekans analizi, t-test ve ANOVA analizleri ile sonuçlara ulaşılmıştır. Araştırma } \\
\text { kapsamında Kuşçuoğlu (2018) tarafından oluşturulan tutum ölçeğindeki ifadelerden yararlanılmıştır. } \\
\text { Çalışma, tarama modeli niteliğini taşımaktadır. Çalışmada tarama yöntemi, değişkenler arasında olan } \\
\text { ilişkilerin ortaya çıkması ayrıca çıkan sonuçların da doğru tahmin edilmesinde oldukça önem taşımıştır. } \\
\text { Bulgular - Müşterilerin cinsiyet ve eğitim düzeyi ile kredi kartı tutumları ölçeklerinden elde edilen } \\
\text { puanlar arasında anlamlı farklılıkların olduğu sonucuna ulaşılmıştır. Bireysel banka müşterilerinin } \\
\text { medeni durumlarına, kredi kartı türüne, ödeme aracı olarak önceliğine, yaşlarına, mesleklerine, aylık } \\
\text { bireysel ve hane halkı gelirine, yapılan harcama miktarına, kredi kartı sayısına ve ödeme şekline göre } \\
\text { kredi kartı tutumları arasında her bir değişken açısından anlamlı farklılık bulunmamıştır. }\end{array}$ \\
\hline
\end{tabular}

Tartışma - Özkan (2015)'ın araştırmasında bireysel banka müşterilerinin cinsiyetleri kredi kartı kullanım tercihlerini etkileyen faktörleri etkilememektedir. Bu araştırmada cinsiyet arası farklılık tespit edilmiştir. Ayrıca Özkan'ın yaptığı çalışmada bekâr müşterilerin demografik özelliklerine bağlı olarak kredi kartı kullanım tutumunun daha çok etkilendiği sonucuna ulaşılmış fakat bu çalışmada bir farklılık olmadığı tespit edilmiştir.

\begin{tabular}{l} 
ARTICLE INFO \\
\hline Keywords: \\
Attitude Towards Credit \\
Cards \\
Consumer Behaviour \\
Individual Bank Customer \\
Participation Bank
\end{tabular}

Received 24 February 2021

Revised 31 May 2021

Accepted 20 June 2021

Article Classification:

Research Article

\section{ABSTRACT}

Purpose - The banking sector has a very important place in terms of credit card attitudes according to the demographic characteristics of the customers. In a period of intense competition, it is important to examine credit card attitudes in order for banks to make the necessary research to make the correct determinations of their customers' preferences. As a general purpose, necessary studies were carried out in the participation bank branch in Ankara, in order to reveal the relationship between the demografic features of individual bank customers in participation branches and their attitudes towards credit cards.

Design/methodology/approach - In accordance with the purpose of the study, an investigation was conducted in line with the responses of 193 individual bank customers who used credit cards in the first six months of the first and second terms of 2020. Using the G*Power Version 3.1.9.6 program, the number of retail bank customers in the population of 111782 individual bank customers, which constitute the population, among the retail bank customers using credit cards at the participation bank branches in Ankara, was determined according to the power of the sample. A questionnaire was applied using the convenience sampling method. Analyzes were made with the SPSS statistical program. 
Results were reached with frequency analysis, t-test and ANOVA analysis. Within the scope of the research, expressions in the attitude scale created by Kuşçuoğlu (2018) were used. The study is a survey model. In the study, the survey method was very important in the emergence of the relationships between the variables and in the correct estimation of the results.

Findings - It is concluded that there are significant differences between the gender and education level of the customers and the scores obtained from the credit card attitude scales. Significant difference was not found between individual bank customers' credit card attitudes in terms of marital status, credit card type, priority as payment, age, profession, monthly personal and household income, amount of spending, number of credit cards and payment method.

Discussion - In Özkan's (2015) research, the gender of individual bank customers does not affect the factors that affect their credit card usage preferences. In this study, a gender difference was found. In addition, in Özkan's study, it was concluded that credit card usage attitudes of single customers were affected more depending on their demographic characteristics, but it was found that there was no difference in this study.

\section{GİRIŞ}

Dünya' da olduğu gibi Türkiye' de de yaygın kullanım alanı bulan kredi kartları, günümüzde en sık kullanılan tüketici finansman aracı haline gelmiştir. Kredi kartları tüketiciye, gelirine ek olarak anında kullanılabilir kredi sağlaması, nakit taşıma riskini ortadan kaldırması, alışveriş bedellerini taksitlendirmeye imkan vermesi gibi kullanıldığı amaca ve yere göre değişen pek çok olumlu özelliğe sahiptir (Kaya, 2009: 120-130). Olumlu özelliklerine rağmen tüketicinin gelecekte elde edeceği geliri önceden kullanmasına neden olduğundan, bilinçli kullanılmadığında yüksek faiz oranı ve işlem bedelleri nedeniyle aşırı borçlanmaya yol açabilmektedir. Bu konuda yapılmış farklı bilimsel çalışmalar kredi kartı borcunun tamamını ödeyemeyerek, borcun kalan kısmı üzerinden faiz ödeyen dolayısıyla sürekli borçlu bir yaşam süren kişi sayısının giderek arttığına dikkat çekmektedir (Durukan vd., 2005: 152). Tüketicinin kredi kartını rasyonel olarak kullanması, ödeme gücünü göz önünde bulundurarak istenmeyen maliyetlerin oluşmaması için sorumluluklarının bilincinde hareket etmesini ifade etmektedir. Literatürde yapılan araştırmalar incelendiğinde kredi kartları konusunda Türkiye' de yapılmış çalışmaların daha çok kredi kartı sahiplerinin demografik özelliklerini ortaya koymaya ve bankaların pazarlama çalışmalarına katkıda bulunmaya yönelik olduğu görülmüştür (Çavuş, 2006: 173187; Aşan, 2007: 256-267). Bazı çalışmalarda ise kredi kartı, para benzeri olması nedeniyle tüketicilerin satın alma kararlarına etki eden faktörler yönünden ele alınarak incelenmiş ve kredi kartının aşırı borçlanmaya sebep olmaması için tüketici bilincinin arttırılmasının önemine değinilmekle yetinilmiştir (Tuğay ve Başgül, 2007: 223). Diğer ülkelerdeki çalışmalarda bulunan örneklerde ise araştırmaların evreninin daha çok öğrencilerden oluştuğu görülmüştür (Hayhoe vd., 1999: 643-656; Warwick ve Mansfield, 2000: 617-626; Nortivilis vd., 2006: 1395-1413). Dolayısıyla bu çalışmada, yapılmış araştırmaların bulguları doğrultusunda kişilerin kredi kartı kullanımlarında etkili olduğu ileri sürülen farklı faktörlerin, kredi kartının rasyonel kullanımını nasıl etkilediğinin incelenmesi amaçlanmıştır. Çalışmanın bununla ilişkili diğer amaçları arasında kredi kartlarının bilinçsizce kullanımı nedeniyle oluşan maliyetlere dikkat çekmek, kredi kartlarının rasyonel kullanımına etki edebilecek faktörleri araştırmak ve ileride bu amaçla yapılabilecek çalışmalara kaynak oluşturmak sıralanabilir.

\section{LITERATÜR TARAMASI}

Kart kullanımı ve tutum farklılıkları ile Chan (1997) tarafından yapılan çalışmada, aktif olmayan kart sahiplerini ayda 10 kereden az kullanım oranıyla, aktif kart sahipleri ise ayda en az 10 kullanım oranı olan kişilerdir şeklinde sınıflandırmıştır. Godwin'e (1997) göre, yalnızca tüketicilerin borçlanma yeteneği bir hanenin borç miktarını değil, aynı zamanda borçlanma isteğini de etkileyebilir. Norton'a (1993) göre, kredi kullanımına yönelik tüketici tutumları, 1930'lar ile 1990'lar arasındaki kredi kullanımındaki dramatik artıştan kısmen sorumlu olabilir. Ismail vd. (2011) ve Godwin (1998), tüketicilerin kredi kullanımına yönelik genel tutumları ile tüketici borcundaki artış arasında 1983'ten 1989'a pozitif bir ilişki olduğunu bildirmektedirler. Alias'a (2001) göre, bu tutum kredi kartı kullanımıyla pozitif yönde ilişkilidir. Chien ve Devaney (2001), demografik ve sosyo-ekonomik değişkenlerin etkisini açıkladıktan sonra bile, tüketici tutumlarının hem taksitli borç hem de kredi kartı borcu ile önemli bir ilişkisi olduğunu belirtmektedir. Chien ve Devaney (2001); Davies ve Lea (1995) ; Hayhoe ve ark. (1999) yaptıkları çalı̧̧malarda, bir kişinin birden fazla kredi kartına sahip olma olasılığının daha yüksek olduğunu ve aynı zamanda önemli miktarda borcu olduğunu ve kredi kartı 


\section{Z. Gül - O. İşcan - H. Ayhan Gökcek 13/2 (2021) 1619-1631}

kullanımına karşı olumlu bir tavır sergilediğini açıklamaktadır. Dahası, kişisel finansal bilgi, tüketicinin karar vermesinde önemli bir bileşendir.

Robb ve Sharpe (2009)'a göre kredi kartı kullanımıyla ilgili bilgiler, lise ve üniversite öğrencileri arasında kişisel finans eğitimini teşvik ederken faydalı olabilir. Üniversite öğrencileri genel olarak mali konular hakkında çok bilgili görünmemektedir. Yine de, çoğunlukla kredi kartlarının etkin kullanıcıları gibi görünmektedirler (Braunsberger ve diğerleri, 2005). Bu nedenle, bu bulgular, kişisel finansal bilginin tüketicilerin finansal karar verme süreçleri üzerinde herhangi bir etkisinin olup olmadığı sorusunu gündeme getirmektedir (Robb 2007. Çeşitli kredi kartı düzenleyen bankalar, yoğun bir şekilde rekabet etmek ve kredi kartı kullanımını artırmak için yerel medyayı kullanarak kapsamlı reklam kampanyaları geliştirmiştir. Buna ek olarak, televizyon, radyo, dergi ve gazete gibi çeşitli kitle iletişim araçları aracılığıyla reklam vermek, onları aktif kart sahibi olmaya teşvik etmenin bir yolu olarak yüksek gelirli profesyonelleri ve beyaz yakalı çalışanları hedeflemektedir (Ramayah ve diğerleri 2002). Kredi kartı kullanımına yönelik tutumların kredi kartı kullanımına katkı sağlayan faktörlerden biri olduğu söyleniyor. Tüketicinin kredi kartlarının kullanımına ve kabul edilebilirliğine yönelik davranışı ve tutumu psikografik nedenlerle farklılık göstermektedir (Yang ve ark. 2007). Xiao vd. (1995) kredi kartlarına yönelik etkililik, bilişsel ve davranışsal tutumları ölçmek için 38 maddelik bir ölçek geliştirmiştir. Duygusal tutumlar, "kredi kartım beni mutlu ediyor" gibi bir ifadeyle yakalanabilen duygusal duyguları içerir. Bilişsel tutumlar, "kredi kartlarının yoğun kullanımı ağır borçla sonuçlanır" gibi bir ifade kullanan düşünceleri içerir. Bu arada, davranışsal tutumlar, "Kredi kartımı sık kullanıyorum" gibi ifadelerle ifade edilen eylemleri içerir. Ayrıca Ahmed ve ark. (2009), kredi kartı kullanmanın temel nedenlerinden birinin, nakit para yerine "plastik para" (kart) getirmenin kolaylığıyla ilgili olduğunu belirtmektedir. Bu nedenle, aşağıdaki hipotez geliştirilmiştir:

H1 Kredi kartı kullanımına yönelik algı ve tutumlar arasında pozitif bir ilişki vardır.

Aile etkisi de kredi kartı kullanımını etkileyen bir faktör olarak görülüyor. Nitekim yapılan bir araştırmada gerek eğitime katılım gerekse aile sosyo-ekonomik düzey aile, eğitim ve ekonomi ilişkisini ortaya koymaktadır. (Tabak, 2020). Ailenin etkisi ve kişisel deneyim, krediyi etkili bir şekilde kullanmayı öğrenmenin temel araçları ve finansal bilginin ana kaynaklarıdır(Hilgert \& Hogarth 2003). Ebeveynler, okullar, akranlar ve medya, bir gencin doğumdan yetişkinliğe kadar öğrenmesinin ve sosyalleşmesinin bir parçasıdır (Mansfield vd 2003). Tüm bu faktörler, bir gencin kredi bilincini veya kredi kartlarıla ilgili avantajlar ve sorunların farkında olmayı etkilemektedir. Ebeveynler, okullar, akranlar ve medya da genç yetişkinin tüketici davranışını etkilemede rol oynar. Bununla birlikte, ebeveynler bir gencin kredi kartı davranışları üzerinde en büyük etkiye sahiptir (Ismail vd, 2011). Finansal sosyalleşme, piyasada etkin bir şekilde çalısmayı öğrenmekten çok daha kapsamlıdır (Danes 1994). Bireylerin finansal uygulanabilirliğine ve refahına katkıda bulunan değerleri, tutumları, standartları, normları, bilgileri ve davranışları edinme ve geliştirme sürecidir.

Jorgensen (2007) ayrıca ebeveynlerin ve akranların genç bireylerin finansal bilgileri, tutumları ve davranışları üzerinde büyük etkileri olduğunu iddia etmektedir. Ebeveynler daha genç yaştaki öğrenciler üzerinde daha büyük bir etkiye sahip olma eğilimindeyken (Ismail ve diğerleri, 2011), öğrenci yaşlandıkça, özellikle üniversite öğrencisi olduktan sonra akran etkisi artmaktadır (Jorgensen 2007). Bu nedenle aşağıdaki hipotez geliştirilmiştir:

H2 Ailenin etkisi ile kredi kartı kullanımına yönelik tutum arasında pozitif bir ilişki vardır.

Ayrıca, kredi kartlarının mülkiyeti ve kullanımının kabul edilebilirliği ile ilgili ülke genelinde İslami faiz yasağı açısından Suudi Arabistan genelinde kredi kartına sahip olma ve kullanım davranışı açısından devam eden bir tartışma mevcuttur (Abdul-Muhmin \& Umar 2007). Dini çekinceler, borçlanmaya yönelik kültürel engeller ve plastik para kullanımına aşina olmama gibi kredi kartlarıyla ilgili konuların derinlemesine incelenmesi gerekmektedir (Ahmed ve diğerleri 2009). Bu nedenle aşağıdaki hipotez geliştirilmiştir:

H3 Dini inanç ile kredi kartı kullanımına yönelik tutum arasında pozitif bir ilişki vardır. 


\section{Z. Gül - O. İşcan - H. Ayhan Gökcek 13/2 (2021) 1619-1631}

\section{YÖNTEM}

\subsection{Araştırmanın Amacı}

Araştırmalardan yola çıkarak katılım banka şubelerindeki bireysel banka müşterilerinden kredi kartı kullanan kişilerin kredi kartına yönelik tutumlarının, bireyler değişik özelliklere göre sınıflandırıldıklarında farklılık gösterebileceği düşünülmektedir. Ankara ilinde yer alan katılım banka şubelerindeki bireysel banka müşterilerinin demografik özellikleri ve kredi kartına yönelik tutumları arasında ilişkiyi ortaya çıkarmak amacıyla araştırma kapsamında toplam hipotez incelemeye alınmıştır. Bu doğrultuda Ankara ilinde yer alan katılım banka şubelerindeki bireysel banka müşterilerinin kişilik özellikleri, kredi kartına yönelik tutumları, kredi kartı tercihini etkileyen faktörler ve aylık kredi kartı kullanım sıklıkları arasında ilişkiyi ortaya çıkarmak amacıyla araştırma kapsamında aşağıdaki sorulara cevap aranmıştır. Her bir soruya ilişkin yokluk hipotezi (Ho) ve alternatif hipotez (Ha) oluşturularak araştırma soruları bağlamında 12 adet hipotezler test edilmiştir:

H1: Bireysel banka müşterilerinin cinsiyetlerine göre kredi kartı tutumları arasında farklılık vardır.

H2: Bireysel banka müşterilerinin medeni durumlarına göre göre kredi kartı tutumları arasında farklılık vardir.

H3: Bireysel banka müşterilerinin kullandıkları kredi kartı türlerine göre kredi kartı tutumları arasında farklılık vardır.

H4: Bireysel banka müşterilerinin ödeme aracı olarak önceliğine göre kredi kartı tutumları arasında farklılık vardır.

H5: Bireysel banka müşterilerinin yaşlarına göre kredi kartı tutumları arasında farklılık vardır.

H6: Bireysel banka müşterilerinin eğitim düzeylerine göre kredi kartı tutumları arasında farklılık vardır.

H7: Bireysel banka müşterilerinin mesleklerine göre kredi kartı tutumları arasında farklılık vardır.

H8: Bireysel banka müşterilerinin aylık bireysel gelirlerine göre kredi kartı tutumları arasında farklılık vardir.

H9: Bireysel banka müşterilerinin aylık hane gelirlerine göre kredi kartı tutumları arasında farklılık vardır.

H10: Bireysel banka müşterilerinin kredi kartı ile aylık yapılan ortalama harcama miktarlarına göre kredi kartı tutumları arasında farklılık vardır.

H11: Bireysel banka müşterilerinin haftalık kredi kartı sayısına göre kredi kartı tutumları arasında farklılık vardir.

H12: Bireysel banka müşterilerinin günlük kredi kartı ödeme şekline yönelik algılarına göre kredi kartı tutumları arasında farklılık vardır.

\subsection{Araştırmanın Modeli}

Yapılan araştırmada bireysel banka müşterilerinin demografik özellikleri ile kredi kartına yönelik tutumları arasındaki ilişkiyi ortaya çıkarmak amaçlanmışır. Bu amaç bağlamında yapılan araştırma tarama modeli niteliğindedir. Tarama araştırma yöntemi, değişkenler arasındaki ilişkileri açıklama ve sonuçları tahmin etme fırsatı sunmaktadır. Araştırmada kredi kartı tutumları ile demografik farklılıkların belirlenebilmesi için t-test ve ANOVA testlerinden faydalanılmıştır. Analizler SPSS 24 istatistik programı ile yapılmıştır.

\subsection{Evren ve Örneklem}

Araştırmanın amacına uygun olarak belirlenen evren 2020 yılının birinci ve ikinci döneminde (ilk altı ay) Ankara ilinde yer alan katılım banka şubelerindeki bireysel banka müşterilerinden kredi kartı kullanan kişiler oluşturmaktadır. Araştırmanın örneklemini kolayda örnekleme yöntemi ile belirlenen kredi kartı kullanan 193 bireysel banka müşterileri oluşturmaktadır. G*Power Version 3.1.9.6 programı kullanılarak Ankara ilinde yer alan katılım banka şubelerindeki bireysel banka müşterilerinden kredi kartı kullanan kişiler arasından evreni oluşturan 111782 bireysel banka müşterisi içerisinden örneklemin gücüne göre sayısı belirlenmiştir. Orta etki büyüklügünün 0,30 olarak alfa yanılma payının 0.05 olduğu ve power gücünün ise 0.99 olarak belirlendiği araştırmanın çift yönlü toplam örneklem büyüklüğü 188 olarak hesaplanmıştır (Faul, vd.,1992). Bu bağlamda 


\section{Z. Gül - O. İşcan - H. Ayhan Gökcek 13/2 (2021) 1619-1631}

hedeflenen örneklemin üzerinde veriye ulaşmak için 193 banka müşterisinden veri toplanmıştır. Bu sayede ulaşılan örneklemin $G^{*}$ Power programına dayalı kriterlere göre belirlenen örneklem sayısının üzerinde olduğu ve evreni temsil edebilecek yeterlikte olduğu ortaya konmuştur. Belirlenen örnekleme ulaşabilmek için örnekleme türlerinden kolayda örnekleme yöntemi benimsenmiştir. Kolayda örnekleme, bir bölge söz konusu değilse, yakın çevrede bulunan ve ulaşılması kolay, elde mevcut ve araştırmaya katılmak isteyen (gönüllü) bireyler üzerinde yapılan örneklemedir (Erkuş, 2013, ss. 122).

\subsection{Veri Toplama Arace}

Bu araştırma kapsamında Ankara'da yer alan katılım banka şubelerindeki bireysel banka müşterilerinden kredi kartı kullanan kişilerin kredi kartına yönelik tutumlarının belirlenmesi amaçlanmıştır. Araştırma kapsamında Kuşçuoğlu (2018) tarafından oluşturulan tutum ölçeğindeki ifadelerden yararlanılmıştır. Tutum ölçeğinde yer alan ifadeler incelendikten sonra ölçek maddeleri 193 müşterinin vermiş olduğu cevaplar doğrultusunda analizler gerçekleştirilmiştir.

\subsection{Verilerin Analizi}

Araştırmaya katılan müşterilerden elde edilen veriler öncelikle SPSS 25.0 programına aktarılmıştır. Ardından eksik ve hatalı veri olup olmadığı incelenmiştir. Eksik veriler, veri setinden çıkarıldıktan sonra müşterilerin ölçeklerden almış oldukları puanlar hesaplanmıştır. Bu doğrultuda öncelikle toplam puanlar hesaplanmıştır. Hesaplanan puanların normal dağılım gösterip göstermediğinin tespit edilmesi amacıyla çarpıklık ve basıklık katsayıları hesaplanmıştır. Hesaplanan değerlerin \pm 1 arasında değer aldığı belirlenmiştir. Bu durum, verilerin normal dağılım gösterdiğine işaret etmektedir.

Bireysel banka müşterilerinin cinsiyetlerine ve medeni durumları ile kredi kartı tutumları arasında farklılık olup olmadığının tespit edilmesi amacıyla bağımsız örneklemler $t$ testi hesaplanmıştır.

Bireysel banka müşterilerinin yaşlarına, eğitim düzeylerine, mesleklerine, aylık bireysel gelirlerine, aylık hane gelirlerine, kredi kartı ile aylık yapılan harcama miktarına, kredi kartı sayılarına, haftalık kredi kartı kullanım sıklığına, günlük kredi kartı kullanım sıklığına göre kredi kartı tutumları arasında farklılık olup olmadığının tespit edilmesi amacıyla tek yönlü varyans analizi (One-Way ANOVA) hesaplanmıştır.

Fark testlerinde anlamlılık değeri $\mathrm{p}<0,05$ olarak kabul edilmiştir. Sonuçlar tablolaştırılarak yorumlanmıştır.

\section{BULGULAR}

Araştırmanın amacına uygun olarak belirlenen örneklemi 2020 yılının birinci ve ikinci döneminde (ilk altı ay) Ankara ilinde yer alan katılım banka şubelerindeki bireysel banka müşterilerinden kredi kartı kullanan kişiler oluşturmaktadır. Örnekleme ait demografik bilgiler Tablo-1 de gösterilmektedir.

Tablo 1. Bireysel Banka Müşterilerinin Demografik Özelliklerine İlişkin Frekans ve Yüzde Dağılımları

\begin{tabular}{llcc}
\hline & Kategoriler & $f$ & $\%$ \\
\hline \multirow{2}{*}{ Cinsiyet } & Erkek & 86 & 44,6 \\
& Kadın & 107 & 55,4 \\
\hline \multirow{2}{*}{ Medeni Durum } & Evli & 130 & 67,4 \\
& Bekar & 63 & 32,6 \\
\hline \multirow{4}{*}{ Yaş } & 28 Yaş ve Altı & 37 & 19,2 \\
& $29-32$ Yaş & 58 & 30,1 \\
& 33-36 Yaş & 30 & 15,5 \\
& 37-40 Yaş & 30 & 15,5 \\
& 41 Yaş ve Üstü & 38 & 19,7 \\
\hline \multirow{4}{*}{ Eğitim Düzeyi } & Ortaokul & 22 & 11,4 \\
& Lise & 19 & 9,8 \\
& Ön Lisans & 28 & 14,5 \\
& Lisans & 68 & 35,2 \\
& Yüksek Lisans & 32 & 16,6 \\
Meslek Türü & Doktora & 24 & 12,4 \\
\hline & Memur & 90 & 46,6
\end{tabular}




\begin{tabular}{llcc}
\hline & İşçi & 29 & 15,0 \\
& Serbest Meslek & 34 & 17,6 \\
& Emekli & 11 & 5,7 \\
& Öğrenci & 12 & 6,2 \\
& Ev Hanımı & 17 & 8,8 \\
\hline \multirow{4}{*}{ Aylık Bireysel Gelir } & 2324 TL ve Altı & 23 & 11,9 \\
& $2325-4649$ TL & 68 & 35,2 \\
& $4650-6974$ TL & 57 & 29,5 \\
& 6975 TL ve Üstü & 45 & 23,3 \\
\hline \multirow{3}{*}{ Aylık Hane Geliri } & 4500 TL ve Altı & 39 & 20,2 \\
& $4501-6900$ TL & 45 & 23,3 \\
& 6901-9300 TL & 49 & 25,4 \\
Toplam & 9301 TL ve Üstü & 60 & 31,1 \\
\hline
\end{tabular}

Örnekleme göre, katılımcıların yüzde 55,4'ü kadın (107 kişi), katılımcıların yüzde 67,4' ü evlidir (130 kişi).

Yaş çalışmaya katılanların yaşını gösteren sürekli bir değişkendir. Bu değişken, 28 ve altı, 29-32, 33-36, 37-40 ve 41 ve üstü olmak üzere 5 gruba ayrılmıştır. Belirlenen yaş gruplarından 28 yaş altı grubunda eğitimden yeni mezun genç bireyler bulunmakta iken, 29-32 yaş grubu sosyal yaşam ve kariyerle ilgili kararların alındığı dönemdir. 37-40 kariyerlerinde yükselme dönemini ve 41 ve üzeri emekli grubunu oluşturmaktadır. 29-32 yaş grubu ankete katılanların \%30,1'ini oluşturmaktadır.

Eğitim seviyesi, 6 alt değişken ile incelenmiştir. Ankete katılanlar arasında ortaokulu bitirenler ortaokul ve altı grubunda, liseyi bitirmiş olanlar lise grubunda, lise sonrası eğitim alanlar önlisans grubunda, üniversite eğitimini bitirenler lisans, lisans sonrası eğitim alanlar yüksek lisans ve doktora grubunda toplanmıştır. Eğitim düzeyine göre lisans derecesine sahip olanlar çoğunluğu $(\% 35,2)$ oluşturmaktadır.

Meslek, devlet memuru, kendi işi olanlar, işçiler, emekli ve iş gücünün dışında olan öğrenci ve ev hanımları olmak üzere 6 sinıfta incelenmiştir. Devlet memuru değişkeni kamu sektöründe yönetici, uzman ve memur olarak çalışan bireylerden oluşmaktadır. Meslek grupları araştırılırken, emekli olmayıp işgücünün dışında olanlar ile emekli ve iş gücünün dışında olan bireylerin birbirinden ayırt edilmesi amacıyla emekli seçeneği de meslek sorularına eklenmiştir. Meslek grupları arasında en büyük pay ile memur olarak çalışanlar $(\% 46,6)$ çoğunluktadır.

Katılımcıların gelir düzeyi 2325-4649 TL $(\% 35,2)$ arasında olanlar çoğunluğu oluşturmaktadır. Hane halkı gelir seviyesi, hane halkı üyelerinin toplam aylık gelirlerini gösteren sürekli bir değişkendir. Hane halkı geliri 9301 TL ve Üstü üzerinde olanlar $(\% 31,1)$ çoğunluktadır. Hane halkı gelirinin yüksek olması bireylerin kredi kartı kullanma tercihini etkilemektedir.

Tablo 2. Cinsiyet Değişkenine göre Kredi Kartı Tutumu Farklılaşması

\begin{tabular}{llcccccc}
\hline Ölçek & Cinsiyet & $\mathbf{N}$ & Ortalama & s.s. & sd & t & p \\
\hline Kredi Kartı & Erkek & 86 & 35,1744 & 4,65060 & \multirow{2}{*}{191} & \multirow{2}{*}{3,578} & \multirow{2}{*}{,000 } \\
Tutum Ölçeği & Kadın & 107 & 32,8037 & 4,51296 & & & \\
\hline
\end{tabular}

Kredi kartı tutum ölçeğine ilişkin bireysel banka müşterilerinin cinsiyetlerine göre tutumları arasında $\mathbf{t}_{(191)}=3,578, p=0,000<0,05^{\prime}$ e göre anlamlı farklılık olduğu görülmektedir. Bu anlamlı farklılık erkek müşterilerin tutumlarının ( $\bar{X}=35,1744)$, kadın müşterilerin tutumlarından $(\bar{X}=32,8037)$ daha yüksek olmasından kaynaklanmaktadır. Başka bir ifadeyle müşterilerin cinsiyetleri kredi kartına karşı tutumlarını etkileyen değişken olduğu sonucuna ulaşılmıştır. Bu fark, erkek müşterilerin kadın bireysel kullanııılardan daha çok etkilenmesinden kaynaklanabilir. 
Z. Gül - O. İşcan - H. Ayhan Gökcek 13/2 (2021) 1619-1631

Tablo 3. Medeni Durum Değişkenine göre Kredi Kartı Tutumu Farklılaşması

\begin{tabular}{|c|c|c|c|c|c|c|c|}
\hline Ölçek & $\begin{array}{l}\text { Medeni } \\
\text { Durum }\end{array}$ & $\mathbf{N}$ & Ortalama & s.s. & sd & $\mathbf{t}$ & $\mathrm{p}$ \\
\hline Kredi Kartı & Evli & 130 & 33,7154 & 4,81154 & \multirow{2}{*}{191} & \multirow{2}{*}{,- 612} & \multirow{2}{*}{,541 } \\
\hline Tutum Ölçeği & Bekâr & 63 & 34,1587 & 4,52665 & & & \\
\hline
\end{tabular}

Kredi kartı tutum ölçeğine ilişkin bireysel banka müşterilerinin medeni durumlarına göre tutumları arasında $\mathrm{t}(191)=-0,612, p=0,541>0,05$ 'e göre anlamlı farklılık olmadı̆̆ görülmektedir. Kredi kartı tutumlarına göre medeni durum farklılaşmamaktadır, müşterilerin evli veya bekâr olması kredi kartı tutumlarını etkilememektedir.

Tablo 4. Kredi Kartı Türü Değişkenine göre Kredi Kartı Tutumu Farklılaşması

\begin{tabular}{llcccccc}
\hline Ölçek & Kredi Kartı Türü & N & Ortalama & s.s. & sd & t & p \\
\hline Kredi Kartı & Master Card & 91 & 33,5495 & 4,56134 & \multirow{2}{*}{191} & \multirow{2}{*}{, 864} & \multirow{2}{*}{389} \\
Tutum Ölçeği & Visa & 102 & 34,1373 & 4,85031 & & & \\
\hline
\end{tabular}

Kredi kartı tutum ölçeğine ilişkin bireysel banka müşterilerinin kullandıkları kredi kartı türüne göre tutumları arasında $\mathrm{t}_{(191)}=-0,864, \mathrm{p}=0,389>0,05$ 'e göre anlamlı farklılık olmadığ 1 görülmektedir. Kredi kartı tutumlarına göre kredi kartı türü farklılaşmamaktadır, müşterilerin master card veya visa kullanmaları kredi kartı tutumlarını etkilememektedir.

Tablo 5. Ödeme Aracı Önceliği Değişkenine göre Kredi Kartı Tutumu Farklılaşması

\begin{tabular}{|c|c|c|c|c|c|c|c|}
\hline Ölçek & $\begin{array}{l}\text { Ödeme Aracı } \\
\text { Öncelik }\end{array}$ & $\mathbf{N}$ & Ortalama & s.s. & sd & $\mathbf{t}$ & $\mathbf{p}$ \\
\hline Kredi Kartı & Kredi Kartı & 129 & 33,5703 & 4,83700 & \multirow{2}{*}{191} & \multirow{2}{*}{$-1,200$} & \multirow{2}{*}{,232 } \\
\hline Tutum Ölçeği & Nakit & 65 & 34,4308 & 4,44047 & & & \\
\hline
\end{tabular}

Kredi kartı tutum ölçeğine ilişkin bireysel banka müşterilerinin ödeme aracı olarak önceliğine göre tutumları arasında t (191)=-1,200, p=0,232>0,05'e göre anlamlı farklılık olmadı̆̆ görülmektedir.

Tablo 6. Müşterilerin Yaş Değişkenine göre Kredi Kartı Tutumu Farklılaşması

\begin{tabular}{lllcccc}
\hline & Yaş & N & Ortalama & s.s. & F & $\begin{array}{c}\text { Post Hoc } \\
\text { (Tukey) }\end{array}$ \\
\hline & 28 ve Altı & 37 & 34,5405 & 4,29854 & & \\
Kredi Kartı & $29-32$ & 58 & 34,5690 & 4,34928 & & \\
Tutum Ölçeği & $33-36$ & 30 & 33,3000 & 4,54973 & 2,217 &, 069 \\
& $37-40$ & 30 & 34,5000 & 5,36110 & & \\
& 41 ve Üstü & 38 & 32,0526 & 4,92071 & & \\
\hline
\end{tabular}

Kredi kartı tutum ölçeği ilişkin bireysel banka müşterilerinin yaşlarına göre tutumları arasında $\mathrm{F}_{(4 ; 188)}=2,217$, $\mathrm{p}=0,069>0,05^{\prime}$ e göre anlamlı farklılık olmadığ görülmektedir.

Tablo 7. Müşterilerin Eğitim Değişkenine göre Kredi Kartı Tutumu Farklılaşması

\begin{tabular}{|c|c|c|c|c|c|c|c|}
\hline & Eğitim Düzeyi & $\mathbf{N}$ & Ortalama & s.s. & $\mathbf{F}$ & $\mathbf{p}$ & $\begin{array}{l}\text { Post Hoc } \\
\text { (Tukey) }\end{array}$ \\
\hline \multirow{6}{*}{$\begin{array}{l}\text { Kredi Kartı } \\
\text { Tutum Ölçeği }\end{array}$} & Ortaokul ve altı & 22 & 30,2273 & 2,82728 & \multirow{6}{*}{3,708} & \multirow{6}{*}{,003 } & \multirow{6}{*}{$\begin{array}{l}\text { Ortaokul } \\
\text { ve altı, } \\
\text { Lisans, } \\
\text { Yüksek } \\
\text { Lisans }\end{array}$} \\
\hline & Lise & 19 & 33,8947 & 5,09787 & & & \\
\hline & Ön Lisans & 28 & 33,7143 & 4,62567 & & & \\
\hline & Lisans & 68 & 35,0000 & 4,72845 & & & \\
\hline & Yüksek Lisans & 32 & 34,2188 & 4,64712 & & & \\
\hline & Doktora & 24 & 33,6250 & 4,66078 & & & \\
\hline
\end{tabular}

Kredi kartı tutum ölçeği ilişkin bireysel banka müşterilerinin eğitim düzeylerine göre tutumları arasında $F_{(5 ; 187)}=3,708$ p=0,003<0,05'e göre anlamlı farklılık olduğu görülmektedir. Analize göre anlamlı olan değişkenler ortaokul ve altı, lisans ve yüksek lisanstır. Bu anlamlı farklılık lisans eğitim düzeyine sahip müşterilerin 
tutumlarının ( $\bar{X}=35,0000)$ ortaokul ve altı ve yüksek lisans müşterilerin tutumlarından daha yüksek olmasından kaynaklanmaktadır. Kredi kartının kullanımının başladığı dönemden günümüze kadar ortaokul ve daha alt kademeden mezun olan bireysel banka müşterilerinin lisans ve yüksek lisans mezunlarının sayısına göre daha az olmasının sonucunda geçmiş alışkanlıkları nakit kullanma üzerine kurulu olan bu grubun kredi kartını kullanma alışkanlığının daha az olması sonucu çıkarılabilir.

Tablo 8. Müşterilerin Meslek Değişkenine göre Kredi Kartı Tutumu Farklılaşması

\begin{tabular}{llcccccc}
\hline & Meslek & N & Ortalama & s.s. & F & p & $\begin{array}{c}\text { Post Hoc } \\
\text { (Tukey) }\end{array}$ \\
\hline & Memur & 90 & 33,8778 & 3,99952 & & & \\
& İşçi & 29 & 32,4138 & 4,93904 & & & \\
Kredi Kartı & Serbest Meslek & 34 & 34,5588 & 5,15335 & & & \\
Tutum Ölçeği & Emekli & 11 & 34,9091 & 6,68513 & 1,546 &, 177 & \\
& Öğrenci & 12 & 36,0000 & 3,86123 & & &
\end{tabular}

Kredi kartı tutum ölçeğine ilişkin bireysel banka müşterilerinin mesleklerine göre tutumları arasında $\mathrm{F}_{(5 ; 187)}=1,546, \mathrm{p}=0,177>0,05^{\prime}$ e göre anlamlı farklılık olmadığ görülmektedir.

Tablo 9. Müşterilerin Aylık Bireysel Gelirler Değişkenine göre Kredi Kartı Tutumu Farklılaşması

\begin{tabular}{llcccccc}
\hline & $\begin{array}{l}\text { Aylık Bireysel } \\
\text { Gelir }\end{array}$ & N & Ortalama & s.s. & F & p & $\begin{array}{c}\text { Post Hoc } \\
\text { (Tukey) }\end{array}$ \\
\hline \multirow{3}{*}{ Kredi Kartı } & 2324 TL ve altı & 23 & 34,3913 & 5,43339 & & & \\
Tutum Ölçeği & 2325-4649 TL & 68 & 33,6324 & 5,34456 & \multirow{2}{*}{, 517} & \multirow{2}{*}{671} & \\
& 4650-6974 TL & 57 & 33,4561 & 4,00031 & & & \\
& 6975 TL ve Üstü & 45 & 34,4444 & 4,18632 & & & \\
\hline
\end{tabular}

Kredi kartı tutum ölçeğine ilişkin bireysel banka müşterilerinin aylık bireysel gelirlerine göre kredi kartı tutumları arasında $\mathrm{F}_{(3 ; 189)}=0,517 \mathrm{p}=0,0671>0,05$ 'e göre anlamlı farklılık olmadığı görülmektedir.

Tablo 10. Müşterilerin Aylık Hane Gelir Değişkenine göre Kredi Kartı Tutumu Farklılaşması

\begin{tabular}{|c|c|c|c|c|c|c|c|}
\hline & Aylık Hane Gelir & $\mathrm{N}$ & Ortalama & s.s. & $\mathrm{F}$ & p & $\begin{array}{l}\text { Post Hoc } \\
\text { (Tukey) }\end{array}$ \\
\hline \multirow{4}{*}{$\begin{array}{l}\text { Kredi Kartı } \\
\text { Tutum Ölçeği }\end{array}$} & 4500 TL ve Alt1 & 39 & 33,6154 & 5,27464 & \multirow{4}{*}{2,433} & \multirow{4}{*}{,066 } & \\
\hline & 4501-6900 TL & 45 & 32,4000 & 5,07400 & & & \\
\hline & 6901-9300 TL & 49 & 34,8571 & 4,20813 & & & \\
\hline & 9301 TL ve Üstü & 60 & 34,3000 & 4,25182 & & & \\
\hline
\end{tabular}

Kredi kartı tutum ölçeğine ilişkin bireysel banka müşterilerinin aylık hane gelirlerine göre kredi kartı tutumları arasında $\mathrm{F}_{(3 ; 189)}=2,433 \mathrm{p}=0,066>0,05$ 'e göre anlamlı farklılık olmadığ görülmektedir.

Tablo 11. Müşterilerin Kredi Kartıyla Yapılan Harcama Değişkenine göre Kredi Kartı Tutumu Farklılaşması

\begin{tabular}{lllccccc}
\hline & $\begin{array}{l}\text { Kredi Kartıla } \\
\text { Yapılan Harcama }\end{array}$ & N & Ortalama & s.s. & F & p & $\begin{array}{l}\text { Post Hoc } \\
\text { (Tukey) }\end{array}$ \\
\hline \multirow{3}{*}{ Kredi Kartı } & 1500 TL ve Altı & 69 & 33,9565 & 4,89428 & & & \\
Tutum Ölçeği & 1501-3000 TL & 66 & 33,5909 & 4,55725 & \multirow{2}{*}{, 329} & \multirow{2}{*}{804} & \\
& 3001-4500 TL & 22 & 33,4091 & 5,08648 & & & \\
& 4501 TL ve Üstü & 36 & 34,4444 & 4,53837 & & & \\
\hline
\end{tabular}

Kredi kartı tutum ölçeğine ilişkin bireysel banka müşterilerinin kredi kartıyla yapılan harcamalarına göre kredi kartı tutumları arasında $\mathrm{F}_{(3 ; 189)}=0,329$ p=0,0804>0,05'e göre anlamlı farklılık olmadığı görülmektedir. 
Tablo 12. Müşterilerin Kredi Kartı Sayı Değişkenine göre Kredi Kartı Tutumu Farklılaşması

\begin{tabular}{lcccccc}
\hline & & & & & & $\begin{array}{l}\text { Post Hoc } \\
\text { (Tukey) }\end{array}$ \\
\hline \multirow{2}{*}{ Kredi } & Kredi Kartı Sayısı & N & Ortalama & s.s. & F & p \\
Tutum Ölçeği & 1 & 89 & 33,2022 & 4,84810 & & \\
& 2 & 68 & 34,2794 & 4,37716 & 1,713 &, 183 \\
\hline
\end{tabular}

Kredi kartı tutum ölçeğine ilişkin bireysel banka müşterilerinin kredi kartı sayılarına göre kredi kartı tutumları arasında $\mathrm{F}_{(2 ; 190)}=1,713$, p=0,183>0,05'e göre anlamlı farklılık olmadığ 1 görülmektedir.

Tablo 13. Müşterilerin Kredi Kartı Ödeme Şekli Değişkenine göre Kredi Kartı Tutumu Farklılaşması

\begin{tabular}{llllllll}
\hline & $\begin{array}{l}\text { Kredi Kartı } \\
\text { Ödeme Şekli }\end{array}$ & $\mathbf{N}$ & Ortalama & s.s. & F & p & $\begin{array}{l}\text { Post Hoc } \\
\text { (Tukey) }\end{array}$ \\
\hline & Temassız Ödeme & 56 & 33,6429 & 5,23773 & & & \\
Kredi Kartı & $\begin{array}{l}\text { Şifre Girerek } \\
\text { Ödeme }\end{array}$ & 127 & 34,1969 & 4,30953 & 2,531 & \multirow{2}{*}{082} & \\
$\begin{array}{l}\text { Ödum Ölçeği } \\
\text { İmza İle Ödeme }\end{array}$ & 10 & 30,8000 & 5,82714 & & & \\
\hline
\end{tabular}

Kredi kartı tutum ölçeğine ilişkin bireysel banka müşterilerinin kredi kartı ödeme şekline göre kredi kartı tutumları arasında $\mathrm{F}_{(2 ; 190)}=2,531, \mathrm{p}=0,082>0,05^{\prime}$ e göre anlamlı farklılık olmadığı görülmektedir.

\section{SONUÇ VE TARTIŞMA}

Araştırma kapsamında elde edilen bulguların sonuçları öncelikle bilimsel olarak verilmiş sonrasında elde edilen bu sonuçlar literatürde yer alan diğer çalışmalarla tartışılmıştır. Bu doğrultuda araştırmada bireysel banka müşterilerinin demografik özellikleri ile kredi kartına yönelik tutumları arasındaki ilişkilerin temel anlamda incelenmesi amaçlanmıştır. Bu genel amaç kapsamında ana değişkenler olan demografik özellikler ile kredi kartı kullanım tutumlarının farklılıkları sınanmış, bireysel müşterilerin gerek demografik gerekse kredi kartı kullanımına ilişkin kredi kartı kullanım farklılaşma sonuçlarına ulaşılmıştır. Bu kapsamda araştırmada ulaşılan sonuçlara sistematik olarak aşağıda yer verilmiştir:

Bireysel banka müşterilerinin cinsiyetlerine göre kredi kartı tutumları arasında anlamlı bir ilişki olduğu sonucuna ulaşılmıştır. Başka bir ifadeyle müşterilerin cinsiyetleri kredi kartına karşı tutumlarını etkileyen değişken olduğu sonucuna ulaşılmıştır. Bu fark, erkek müşterilerin kadın bireysel kullanıcılardan daha çok etkilenmesinden kaynaklanmaktadır. Kredi kartı tutum ölçeği analizine göre bireysel banka müşterilerinin eğitim düzeyleri ile tutumları arasında anlamlı farklılık olduğu görülmektedir. Bu anlamlı farklılık ortaokul ve daha alt kademeden mezun olan bireysel banka müşterilerinin kredi kartı tutumlarının, lisans ve yüksek lisans kademelerinden mezun olan bireysel banka müşterilerinin kredi kartı tutumlarından daha düşük olmasından kaynaklanmaktadır. Kredi kartının kullanımının başladığı dönemden günümüze kadar ortaokul ve daha alt kademeden mezun olan bireysel banka müşterilerinin lisans ve yüksek lisans mezunlarının sayısına göre daha az olmasının sonucunda geçmiş alışkanlıkları nakit kullanma üzerine kurulu olan bu grubun kredi kartını kullanma alışkanlığının daha az olması sonucu çıkarılabilir. Bireysel banka müşterilerinin medeni durumlarına, kredi kartı türüne, ödeme aracı olarak önceliğine, yaşlarına, mesleklerine, aylık bireysel ve hane halkı gelirine, yapılan harcama miktarına, kredi kartı sayısına ve ödeme şekline göre kredi kartı tutumları arasında her bir değişken açısından anlamlı farklılık bulunmamıştır.

Araştırmanın değişkenlerinin içeriğine bakılarak literatür incelendiğinde hem teorik hem de kanıta dayalı çalışmalar görülmektedir. Araştırma sonuçları ile ilgili genel bir tartışma ve sonrasında öneriler yer almaktadır. Konuyla ilgili yapılan araştırmalara göre insan ihtiyaç ve arzularının artması ve çeşitlenmesi ile ödeme araçlarında tarihi bir değişim yaşanmaktadır (Yaşar, 2011). Mal ve hizmet alışverişinde para yerine farklı araçların kullanılabileceğinin vurgulanmasından hareketle, bir ödeme şekli olan kredi kartı yeni bir unsur olarak karşımıza çıkmaktadır (Akartepe, 2006). Ancak Akartepe'nin araştırmasının üzerinden geçen süre, kredi kartı kullanımının hem daha sık hem de daha yaygın hale geldiğini göstermiştir. Bu durum, ödeme yöntemlerinin ötesinde insanların harcama psikolojisini ve birçok değişkenle ilişkisini inceleme ihtiyacını ortaya çıkarmıştır. Sonuçta, bir araştırmadaki gizli değişken; Yetenek, tutum ve yetkinlik gibi ölçülemeyen ya 


\section{Z. Gül - O. İşcan - H. Ayhan Gökcek 13/2 (2021) 1619-1631}

da doğrudan gözlemlenemeyen bir değişken olarak düşünülse de (Özkan, 2015) psikolojik faktörlerin dolaylı olarak ölçülebileceğini söyleyebiliriz. Köse (2019), Türkiye'deki kredi kartı pazarındaki teknolojik gelişmelerin kredi kartı ile farklı kullanıcıların ilgisini çekmiştir ve birçok yeni ürün ve hizmetin alternatif bir kanal olarak sunulabilir. Aynı şekilde kredi kartı kullanımında dikkat edilmesi gereken bir diğer hususun da kredi kartı dolandırıcılığı olduğu unutulmamalıdır. Kredi kartı sahtekarlığı her yıl milyarlarca dolar zarara neden olmaktadır (Ünal, 2010; Kültür, 2017).

Hemen hemen her sektörde olduğu gibi, teknolojik gelişimle birlikte ödeme sistemlerinde de yeni gelişmeler yaşanmaktadır. Örneğin kredi kartı, internet bankacılığı ve elektronik para gibi yeni ürünlerin hizmete sunulabilmesi teknolojik gelişme sayesinde gerçekleşmiştir. Son zamanlarda bu tür finansal yeniliklerin nasıl algılandığı kullanma biçimine kültürel hayata etkileri tartışılmaya başlanmıştır. Bu nedenle bankalar, tüketicilerle doğrudan iletişimde bulunmak suretiyle onların ihtiyaç ve isteklerini saptama ve zaman içinde bankacılık sektöründe meydana gelen değişmeleri izlemek zorundadır (Akartepe, 2006). Kredi kartlarının tarihsel gelişimi ve Türkiye'deki yeri hakkında genel bilgilerin yanı sıra, kredi kartı sahipliğini etkileyen faktörlerin belirlenmesidir. Türkiye'de kredi kartı çıkaran çeşitli banka ve kredi kuruluşlarındaki uygulamalar incelenerek Bankalar Arası Kart Merkezi'nin kuruluş amaçları ve faaliyetleri üzerinde kısaca durulmuştur. Kredi kartı sahipliğini etkileyen faktörler meslek, net gelir ve eğitim düzeyi olarak saptanmıştır (Atıcı, 1999). Tüketicilerin kredi kartı hizmetinden beklentilerini ortaya koymayı hedefleyen bir çalışmanın sonucunda bankaların kart hamili ve üye işyerlerinin beklentilerini tam olarak karşılayamadıkları görülmüştür. Yerine getirilemeyen beklentilerin çoğunluğunu teknik konular oluşturmaktadır, ülkemizdeki genel ekonomik durumun düzelmesiyle teknik yetersizliklerin kısa sürede çözülebileceğine inanılmaktadır. Bu inancın nedeni, bankaların sorunun farkında olmaları ve çözüme yönelik faaliyetler içinde olmalarıdır (Demir, 1994). Piyasa düzenleyiciler ve politika yapıcılar için kritik bir bilgi olan pazar gücünü ve dolayısıyla da bankacılık sektörü piyasa yapısı önem arz etmektedir. Türkiye bankacılık sektörünün pazar gücü 0,11, piyasa yapısı ise tekelci rekabet olarak tespit edilmiştir. Bu sonuç, hem Türkiye'nin yaşadığı kriz ve yeniden yapılandırmaların bir başarı hikâyesine dönüştürüldügüne hem de daha düşük pazar gücünün ve daha yüksek rekabetin elde edilmesi için daha düşük bir oranın elde edilmesi hedefine işaret etmektedir (Demirel, 2014). Dolayısıyla harcama başta olmak üzere kredi kartı kullanımına yönelik yapılan araştırmaların hatta daha da ötesinde taramadan daha çok çeşitli modellerle geleceğin kurgulanması ve daha derin analizlerin yapılması gereklilik olduğu literatürle sabittir. Bu nedenle bu araştırmada kurulan modelin doğrulanıp elde edilen veriden hareketle elde edilen bilginin niteliğini doğrular niteliktedir.

Gül (2013) faizsiz bankacılığı İslami ilkelere uygun olarak fon toplayan ve bu fonları ihtiyacı olanların kullanımına sunan bir bankacılık türü olarak tanımlamıştır. Araştırmada faizsiz bankacılık olarak da görülen "katılım bankacılığı" üzerinde durulmuştur. Katılım bankacılığı, faizsiz çalışma prensibine dayalı, her türlü bankacılık faaliyetini bu ilkeye göre yürüten, mevduat toplama ve fon kredilendirme işlemlerinde kar zarar esasına göre çalışan bir bankacılık modelidir (Tat, 2014). Tat'ın yaptığı bu araştırmaya göre bankacılık sistemlerinin de farklılaştığı, faizsiz kazanç ve harcama sistemlerinin ön plana çıktığı görülmektedir. Katılım bankacılığında önemli olan bankacılık işlem ve faaliyetlerinin faizsiz bankacılık ilkelerine göre yürütülmesidir (Tekçam, 2017). Son olarak teknolojik değişimler yaşayan ve elektronik ticaretin gelişmesiyle dünyada insanlar, eksenin dijital dönüşümüne giren işletmeler ve kurumlar, dünyayı ve Türkiye'de bankacılık sektörünü ele geçirmektedir (Yerlikaya, 2017).

Teknolojik gelişmelerle birlikte her alanda olduğu gibi ödeme sistemlerinde de yeni gelişmeler ortaya çıkmaktadır. Örneğin, teknolojik gelişmeler sayesinde kredi kartları, internet bankacılığı, elektronik para ve kripto para gibi yeni ürünler hizmete girmiştir. Son zamanlarda, bu tür finansal yeniliklerin nasıl algılandığı, nasıl kullanıldığı ve kültürel yaşama etkileri tartışıldı. Bu nedenle bankalar tüketicilerle doğrudan iletişim kurmak, ihtiyaç ve taleplerini belirlemek ve zaman içinde bankacılık alanında meydana gelebilecek değişiklikleri izlemek zorundadır (Akartepe, 2006). Türkiye'de olduğu kadar özel kredi kartlarının tarihsel gelişimi ve yeri hakkında genel bilgiler de göz önünde bulundurulduğunda, kredi kartı sahipliğini etkileyen faktörlerin belirlenmesi önemlidir. Bankalararası Kart Merkezi, kredi kartı sahipliğini etkileyen faktörleri meslek, net gelir ve eğitim düzeyi olarak belirlemiştir (Atıc1, 1999). Demir (1994) tarafından tüketicilerin kredi kartı hizmetinden beklentilerini ortaya çıkarmak amacıyla yaptığı araştırma sonucunda bankaların kart sahiplerinin ve üye işletmelerin beklentilerini tam olarak karşılayamadığ tespit edilmiştir. Karşılanmayan beklentilerin çoğu teknik sorunlardır. Ülkedeki genel ekonomik durumun iyileştirilmesiyle teknik 


\section{Z. Gül - O. İşcan - H. Ayhan Gökcek 13/2 (2021) 1619-1631}

eksikliklerin hızla çözülebileceğine inanılıyor. Bu inancın ortaya çıkmasının nedeni, bankaların sorunun farkında olmaları ve çözüme yönelik çalışmalarıdır (Demir, 1994). Piyasa düzenleyicileri ve politika yapıcılar için kritik bir bilgi olan piyasa gücü ve bankacılık sektörü piyasa yapısı çok önemlidir. Türkiye bankacılık sektörünün pazar gücü 0,11'dir ve bankacıllk sektörü tekelci rekabet piyasa yapısı olarak belirlenmiştir. Bu sonuçlar, daha düşük bir hedef oranına ulaşıldığını ve Türkiye'nin krizi yaşadığını ve yeniden yapılanmaların hem daha düşük pazar gücü elde etmek hem de daha yüksek rekabet için bir başarı öyküsüne dönüştügünü göstermektedir (Demirel, 2014). Ayrıca harcamalar başta olmak üzere kredi kartı kullanımına yönelik çalışmalar, tarama yapmaktan ziyade çeşitli modellerle gelecekteki olasılıkların belirlenmesi ve daha derin analizler yapılması gerekliliğini ortaya koymuştur. $\mathrm{Bu}$ nedenle bu araştırma, kurulan modelin doğrulanmasıyla elde edilen verilere dayalı olarak elde edilen bilgilerin kalitesini doğrulamaktadır.

Türkiye'de faizsiz bankacılığın görünen yüzü, Katılım Bankaları, faiz oranları kullanılan risksiz faiz oranlarından arındırılmış olarak görülebilir (Gül, 2013). Tekçam (2017) 'ın banka personelinin de katılımıyla gerçekleştirdiği uyum denetimi ile ilgili araştırması ve araştırma sonuçlarına göre Türkiye için İslami bankacılık ilkelerine bir model önerilmiştir. Modelin Türkiye'de sigorta sağlama menfaatinin kontrolüne katkı sağlaması beklenmektedir (Tekçam, 2017). Başbakanlığa bağlı özel bir bankanın mevduat sahiplerinin sınıflandırma ve genel tavırlarını, kredi kartı işlemlerini hangi bankacılık kanallarını kullanarak yaptıklarını ve kredi kartının özelliklerinden memnuniyetlerini incelemek için araştırma konuları. Aynı zamanda kart özelliklerinden memnuniyetlerine göre sinfflandırılırlar. Analiz kanalı kullanım tercihlerinde kart özelliklerinin memnuniyetine göre 4 sınıf olduğu görülmüştür. Bu sinıflar veya kart tercihleri eğitim ve yaş gruplarına göre incelenmiştir (Özkan, 2015). Ancak Özkan'ın araştırmasında bireysel banka müşterilerinin cinsiyetleri kredi kartı kullanım tercihlerini etkileyen faktörleri etkilememektedir. Bu yönüyle iki araştırmanın sonucu birbirini desteklememektedir. Özkan'ın yaptığı çalışmadan çıkan farklı bir sonuç olarak ise bekâr müşterilerin demografik özelliklerine bağlı olarak kredi kartı kullanım tutumu, sıklığı ve kredi kartının kullanım faktörlerini daha çok etkilediği sonucuna ulaşılmıştır. İki çalışma bu yönüyle de birbirini desteklememektedir. Demografik değişkenlerden ise yaşa bakıldığında 37 yaş ve 41 yaş üstü kullanıcıların kredi kartını daha az tercih ettikleri ve aylık kredi kartı kullanım sıklıklarına bakıldığında ise durumun farklılaşarak yaş büyüdükçe kullanım sıklığı arttı̆̆ı sonucuna ulaşılmıştır. Dolayısıyla kredi kartı kullanımına ilişkin demografik bir takım değişkenlerle ilişki sonuçlara bakıldığında her ne kadar çalışma grubunun farklı dinamikleri olsa da genel olarak benzerlik gösterdiği görülmektedir.

Araştırmanın kredi kartı kullanım faktörlerinin belirlenmesi ve bununla birlikte tüketim alışkanlıklarının değerlendirilmesi, farklı finansal ödeme yöntemleri ile karşılaştııılması ve bu gibi değişkenlerin birbirleri ile ilişkilerini inceleyen araştırmalara kaynak olacağı düşünülmektedir.

\section{KAYNAKÇA}

Abdul-Muhmin, A. G. and Umar, Y. A. (2007). Credit card ownership and usage behavior in Saudi Arabia: The impact of demographics and attitudes toward debt. Journal of Financial Services Marketing, 12, 219235.

Ahmed, A., Amanullah, A. and Hamid, M. (2009). Consumer perception and attitude towards credit card usage: A study of Pakistani consumers. Journal of Comparative International Management, 12(1), 47-57.

Akartepe, G. (2006). Hizmet pazarlamasında kredi kartı pazarlama süreci, kredi kartı kullanıcılarına yönelik araştırma. (Yüksek Lisans Tezi). Gazi Üniversitesi, Sosyal Bilimler Enstitüsü, Ankara.

Alias, H. (2001). Consumption behaviour: A study on consumer's attitude on spending using credit card and its affect on credit card debt. Unpublished MBA Dissertation, Universiti Sains Malaysia, Penan.

Aşan, Z. (2007). Kredi Kartı Kullanan Müşterilerin Sosyo Ekonomik Özelliklerinin Kümeleme Analizi ile İncelenmesi, Dumlupınar Üniversitesi Sosyal Bilimler Enstitüsü Dergisi, (17), 256-267.

Atıcı, H. (1999). Kredi kartı sahipliğini etkileyen faktörlerin ekonometrik modellerle tespit edilmesi ve bir uygulama örneği. (Yüksek Lisans Tezi). Gazi Üniversitesi, Sosyal Bilimler Enstitüsü. Ankara. 


$$
\text { Z. Gül - O. İşcan - H. Ayhan Gökcek 13/2 (2021) 1619-1631 }
$$

Braunsberger, K., Lucas, A. and Roach, D. (2005). Evaluating the efficacy of credit card regulation. International Journal of Bank Marketing, 23(3), 237-254.

Chan, Y. K. (1997). Demographic and attitudinal differences between active and inactive credit cardholders: The case of Hong Kong. International Journal of Bank Marketing, 15(4), 117-125.

Chien, Y. and Devaney, S.A. (2001). The effects of credit attitude and socioeconomic factors on credit card and installment debt. Journal of Consumer Affairs, 35, 162-179.

Çavuş, M. F. (2006). Bireysel finansmanın temininde kredi kartları: Türkiye'de kredi kartı kullanımı üzerine bir araştırma. Selçuk Üniversitesi Sosyal Bilimler Enstitüsü Dergisi, 15, 173-189.

Danes, S. M. (1994). Parental perceptions of children's financial socialization. Journal of Financial Counseling and Planning, 5, 127-146.

Davies, E. and Lea, S. E. G. (1995). Student attitudes to student debt. Journal of Economic Psychology, 16, 663679.

Demir, D. (1994). Banka kredi kartı hizmetlerinin üye işyerleri ve kart hamilleri açısından değerlendirilmesi, (Yüksek Lisans Tezi). Karadeniz Teknik Üniversitesi, Sosyal Bilimler Enstitüsü, Trabzon.

Demirel, O. (2014). Türkiye'de bankacıllk sektöründe pazar gücü araştırması. (Doktora Tezi). Süleyman Demirel Üniversitesi, Sosyal Bilimler Enstitüsü, Ankara.

Durukan, T., H., Elibol ve M. Özhavzalı (2005). Kredi Kartlarındaki Taksit Uygulamasının Tüketicinin Harcama Alışkanlıkları Üzerindeki Etkisini Ölçmeye Yönelik Bir Araştırma (Kırıkkale İli Örneği), Selçuk Üniversitesi Sosyal Bilimler Enstitüsü Dergisi, (13), 143-153.

Erkuş, A. (2013). Davranış Bilimleri İçin Bilimsel Araştırma Süreci. Ankara: Seçkin.

Faul, F., Erdfelder, E., Lang, A.-G., \& Buchner, A. (1992). G*Power Version 3.1.9.6. Germany: University Kiel.

Godwin, D. D. (1997). Dynamics of households' income, debt, and attitudes toward credit, 1983-1989. The Journal of Consumer Affair, 31(2), 303-325

Gül, E. (2013). Faizsiz bankacılıkta risklere karşı aktifve pasif yönetimi: Türkiye katılım bankaları üzerine bir uygulama. (Yüksek Lisans Tezi). Erciyes Üniversitesi, Sosyal Bilimler Enstitüsü, Kayseri.

Hayhoe, C. R., Leach, L. and Turner, P. R. (1999). Discriminating The Number Of Credit Cards Held By College Students Using Credit And Money Attitudes, Journal of Economic Psychology, 20(6), 643- 656.

Hilgert, M. A. and Hogarth, J. M. (2003). Household financial management: The connection between knowledge and behavior. Federal Reserve Bulletin July, 309-322.

Ismail, S., Serguieva, A. and Singh, S. (2011). Integrative model to students' attitude to educational loan repayment: A structural modelling approach. Journal of International Education in Business, 4(2), 125135.

Jorgensen, B. L. (2007). Financial literacy of college students: Parental and peer influences. Unpublished Master Thesis. Virginia Polytechnic Institute and State University, Virginia.

Kaya, F. (2009). Kredi Kartlarının Sinfflandırllması. Türkiye'de Kredi Kartı Uygulaması, İstanbul, Türkiye Bankalar Birliği.

Kuşçuoğlu Yılmaz, Ş. (2018). Kompulsif Satın Alma, Beş Faktör Kişilik Özellikleri, Kredi Kartı Kullanımı ve Kredi Kartına Yönelik Tutum Arasındaki İlişki: Dumlupınar Üniversitesi Örneği, (Yüksek Lisans Tezi). https://tez.yok.gov.tr/UlusalTezMerkezi/ sayfasından erişilmiştir.

Kültür, Y. (2017). Kredi kartı sahtekârlıklarının tespiti için yeni model önerileri. (Doktora Tezi). Boğaziçi Üniversitesi, Fen Bilimleri Enstitüsü, İstanbul.

Mansfield, P. M., Pinto, M. B. and Parente, D. H. (2003). Self control and credit card use among college students. Psychological Report, 92, 1067-1078. 


$$
\text { Z. Gül - O. İşcan - H. Ayhan Gökcek 13/2 (2021) 1619-1631 }
$$

Norvitilis, J. M., Osberg, T. M., Young, P., Mervin, M. M., Roehling, P. V. and Kamas, M. M. (2006). Personality Factors, Money Attitudes, Financial Knowledge and Credit Card Debt in College Students, Journal of Applied Social Psychology, 36(6), 1395- 1413.

Özkan, B. (2015). Kredi kartı kullanım alışkanlıkları üzerine gizli sınıf analizi. (Yüksek Lisans Tezi). Yıldız Teknik Üniversitesi, Fen Bilimleri Enstitüsü, İstanbul.

Ramayah, T., Noor, N., Nasurdin, A. M. and Choo, L. H. (2002). Cardholders' attitude and bank credit card usage in Malaysia: An exploratory study. Asian Acade my of Management Journal, 7(1), 75-102.

Robb, C. A. (2007). College students and credit card use: The effect of personal financial knowledge on debt behavior. A Dissertation presented to the Faculty of the Graduate School at the University of Missouri-Columbia, $1-151$.

Robb, C. A., \& Sharpe, D. L. (2009). Effect of personal financial knowledge on college students' credit card behavior. Journal of Financial Counseling and Planning, 20(1), 25-43.

Tabak, H. (2020). Eğitime Aile Katılımı: Sosyo-Ekonomik Özellikler Etkiliyor Mu?. Ondokuz Mayıs Üniversitesi Eğitim Fakültesi Dergisi, 39(1), 104-121.

Tat, H. (2014). Katılım bankacılığı (Faizsiz Bankacıllk) sistemi Türk bankacıllk sistemine kazandırdı̆̆ı ürünler Türk bankacılık sektöründeki yeri ve gelişimi. (Yüksek Lisans Tezi). İstanbul Aydın Üniversitesi, Sosyal Bilimler Enstitüsü, İstanbul.

Tekçam, R. (2017). Faizsiz bankacıllkta denetim: Türkiye için model önerisi. (Doktora Tezi). İstanbul Ticaret Üniversitesi, Finans Enstitüsü, İstanbul.

Tuğay, O. ve Başgül, N. (2007). Önemli Bir Finansman Kaynağı Olarak Kredi Kartları: Kredi Kartlarının Kart Sahiplerinin Harcamaları Üzerindeki Etkisini Belirlemeye Yönelik Burdur İlinde Bir Araştırma, Süleyman Demirel Üniversitesi İktisadi ve İdari Bilimler Fakültesi Dergisi, 12(3), 215-226.

Ünal, M. A. (2010). POS cihazı ve kredi kartı kullanımının ticari yaşamdaki yeri ve önemi. (Yüksek Lisans Tezi). Haliç Üniversitesi, Sosyal Bilimler Enstitüsü, İstanbul.

Xiao, J. J., Noring, F. E. and Anderson, J. G. (1995). College students' attitudes toward credit cards. Journal of Consumer Studies and Home Economics, 19, 155-174.

Yang, B., Lester, D. and James, S. (2007). Attitudes toward buying online as predictors of shopping online for British and American respondents. CyberPsychology \& Behaviour, 10(2), 198-203.

Yaşar, H. (2011). Kredi kartlarının seçilmiş iktisadi değişkenler ile ilişkisinin ekonometrik analizi: Türkiye uygulaması. (Yüksek Lisans Tezi). Dumlupınar Üniversitesi, Sosyal Bilimler Enstitüsü, Kütahya.

Yerlikaya, S. (2017). Seçilmiş Avrupa Birliği ülkeleri ve Türkiye'de dijital bankacıllğın dönüşümü. (Yüksek Lisans Tezi). Bahçeşehir Üniversitesi, Sosyal Bilimler Enstitüsü, İstanbul. 